\title{
Microbial Fermentation Patterns, Diarrhea Incidence, and Performance in Weaned Piglets Fed a Low Protein Diet Supplemented with Probiotics
}

\author{
Konisgmar Escobar García ${ }^{1}$, Tércia Cesária Reis de Souza ${ }^{1 *}$, Gerardo Mariscal Landín², \\ Araceli Aguilera Barreyro ${ }^{1}$, María Guadalupe Bernal Santos ${ }^{1}$, José Guadalupe Gómez Soto ${ }^{1}$ \\ ${ }^{1}$ Doctorado en Ciencias Biológicas, Facultad de Ciencias Naturales, Universidad Autónoma de Querétaro, \\ Querétaro, México \\ ${ }^{2}$ CENID-Fisiología, Instituto Nacional de Investigación Forestal Agrícola y Pecuaria, Colón, México \\ Email: tercia@uaq.mx
}

Received 12 July 2014; revised 6 August 2014; accepted 15 August 2014

Copyright (C) 2014 by authors and Scientific Research Publishing Inc.

This work is licensed under the Creative Commons Attribution International License (CC BY). http://creativecommons.org/licenses/by/4.0/

\section{Open Access}

\section{Abstract}

To evaluate the effects of dietary protein levels and probiotic supplementation on microbial intestinal fermentation, diarrhea incidence, and performance in weaned piglets, 162 piglets were randomly assigned to three treatments: high-protein diet (20\%), with antibiotics (HPa); high-protein diet (20\%), without antibiotics (HP); and low-protein diet, without antibiotics but with probiotics (LPpb). Piglets and feed were weighed weekly to calculate the average daily gain (ADG), average daily feed intake (ADFI), and gain: feed ratio (G:F). Four piglets per treatment were killed on day 21 postweaning to collect ileal and colon digesta for measurement of short-chain fatty acids (SCFAs), branched-chain fatty acids (BCFAs), lactic acid (LA), and ammonia (AM). In the digesta collected from the ileum and colon, piglets fed the HPa diet had the lowest concentration of volatile fatty acids. Additionally, the HP diet produced the highest concentration of BCFAs, while the LPpb diet produced moreacetic, propionic, and butyric acids than the HPa and HP diets. Piglets fed the HP diet had higher incidence and severity of diarrhea than piglets fed LPpb and HPa diets, and similar values were observed between these two groups. The second week postweaning was the most critical for diarrhea measurements; during the second week, animals had higher incidence and severity of diarrhea. Piglets fed the HPa and LPpb diets had similar ADGs, while those fed the HP diet had the poorest ADG. Similar results were observed with ADFI and G:F. A low-protein diet supplemented with probiotics changed the fermentation profile, reducing toxic metabolites, promoting gut health, decreasing the incidence and severity of postweaning diarrhea, and improving the performance of piglets.

\footnotetext{
${ }^{*}$ Corresponding author.
}

How to cite this paper: García, K.E., et al. (2014) Microbial Fermentation Patterns, Diarrhea Incidence, and Performance in Weaned Piglets Fed a Low Protein Diet Supplemented with Probiotics. Food and Nutrition Sciences, 5, 1776-1786. 


\section{Keywords}

\section{Diarrhea, Intestinal Fermentation, Piglet, Probiotics, SCFAs}

\section{Introduction}

The use of vegetable protein sources in diets offered at weaning, when newly weaned piglets have a limited digestive capacity, promotes fermentation of undigested protein by opportunistic microorganisms, producing branched-chain fatty acids (BCFAs) and ammonia (AM). BCFAs and ammonia are toxic metabolites for the intestinal mucosa and most likely trigger of postweaning diarrhea and poor performance in piglets [1] [2]. Thus, postweaning diarrhea is associated with the consumption of high-protein diets [3] [4].

To prevent postweaning diarrhea, piglets are often given antibiotics; however, antibiotics have been banned for use in livestock for human consumption, exacerbating postweaning diarrhea and related problems in piglets. Consequently, research has focused on looking for alternatives to replace antibiotics in piglet diets. One alternative is the use of low-protein diets: it has been hypothesized that consumption of a low crude protein diet reduces the availability of substrates for bacterial fermentation [5] [6] and improves fecal consistency [5] [7]-[9], which have direct effects on postweaning diarrhea [3] [9] [10]. Another alternative is the use of probiotics, which have shown to have beneficial effects on intestinal health and productive performance in newly weaned piglets [10] [11]. While previous studies have evaluated separately the use of low-protein diets and diets including probiotics with different responses, no studies have assessed the effects of combining both treatments.

The aim of this study was to evaluate the effects of a combination of a low protein diet with probiotics on the fermentation patterns of the ileum and colon, the incidence and severity of diarrhea, and piglet performance during the first three weeks postweaning. Additionally, this diet was compared to a high protein diet with or without antibiotics.

\section{Materials and Methods}

The experiment was conducted at the experimental farm of CENID-Physiology (INIFAP, Mexico). The protocol was reviewed and approved by the bioethical committee of the Faculty of Natural Sciences of Autonomous University of Queretaro. The experimental animals were treated according to the guidelines of the Mexican official norm (NOM-062-ZOO-1999) for production, care, and use of animals for experimentation [12] and the guidelines of the International Guiding Principles for Biomedical Research Involving Animals [13].

\subsection{Animals and Diets}

One hundred sixty-two (Fertilis $20 \times$ G Performance, Genetiporc) piglets were used. Animals were weaned at 20 \pm 1.4 days with an average body weight of $6.6 \pm 1.1 \mathrm{~kg}$. Piglets were housed in groups of six per pen, with nine pens per treatment. Experimental treatments (diets) were as follows: high-protein diet (20\%) with antibiotics (HPa); high-protein diet (20\%) without antibiotics (HP); and low-protein diet (16\%) without antibiotics and with probiotics (LPpb), as described in Table 1. High-protein diets provided amino acid requirements for this production phase [14]; lysine, methionine, threonine, tryptophan, and valine were included in the low-protein diet to cover nutritional requirements of the piglets [14]. The probiotic used in the LPpb group included Bacillus subtilis and $B$. licheniformis (1:1).

\subsection{Animal Management, Performance Data, and Fecal Scores}

Piglets were placed in a temperature-controlled room $\left(30^{\circ} \mathrm{C}, 28^{\circ} \mathrm{C}\right.$, and $26^{\circ} \mathrm{C} \pm 2^{\circ} \mathrm{C}$ during the first, second, and third weeks postweaning, respectively). Animals were housed in weaning pens, with a nipple drinker and a feeder with six spaces; piglets had free access to feed and water throughout the entire experimental period. Piglets were weighed at the beginning of the experimental period and then every week thereafter. At the end of each week, the feed intake of each pen was measured by determining the difference between the amount of feed offered and the amount of feed rejected. These values were used to estimate feed efficiency (gain: feed ratio, G:F). To calculate the average daily feed intake (ADFI) and the average daily gain (ADG), the weekly measurements 
Table 1. Ingredients and chemical compositions of experimental diets.

\begin{tabular}{|c|c|c|c|}
\hline & \multicolumn{3}{|c|}{ Treatments } \\
\hline & $\mathrm{HPa}$ & $H P$ & $L P p b$ \\
\hline \multicolumn{4}{|l|}{ Ingredients (\%) } \\
\hline Maize & 43.57 & 43.62 & 55.67 \\
\hline Soybean meal & 15.00 & 15.00 & 4.02 \\
\hline Fish Menhaden meal & 1.00 & 1.00 & 1.00 \\
\hline Soybean protein concentrate & 10.49 & 10.49 & 8.73 \\
\hline Whey dried & 24.69 & 24.69 & 24.69 \\
\hline Maize oil & 2.00 & 2.00 & 2.00 \\
\hline Lysine & 0.22 & 0.22 & 0.50 \\
\hline Aminogut ${ }^{*}$ & 0.80 & 0.80 & 0.80 \\
\hline Threonine & 0.02 & 0.02 & 0.15 \\
\hline Methionine & 0.04 & 0.04 & 0.08 \\
\hline Tryptophan & 0.01 & 0.01 & 0.08 \\
\hline Valine & -- & -- & 0.17 \\
\hline Salt & 0.01 & 0.01 & 0.01 \\
\hline Sodium carbonate & 0.89 & 0.89 & 0.73 \\
\hline Limestone & 0.71 & 0.71 & 0.82 \\
\hline Linco Spectin Premix $^{* *}$ & 0.05 & -- & -- \\
\hline Vitamins and minerals ${ }^{* * * * *}$ & 0.30 & 0.30 & 0.30 \\
\hline Gustor $^{* * *}$ & 0.20 & 0.20 & 0.20 \\
\hline Bioplus 2B $\mathrm{B}^{* * * * *}$ & -- & -- & 0.05 \\
\hline \multicolumn{4}{|l|}{ Chemical Composition } \\
\hline Dry matter (\%) & 89.7 & 91.7 & 90.3 \\
\hline Crude protein (\%) & 20.0 & 19.9 & 16.1 \\
\hline Ash (\%) & 5.9 & 5.8 & 5.6 \\
\hline Crude fat (\%) & 3.4 & 3.6 & 1.8 \\
\hline NDF (\%) & 5.8 & 5.0 & 5.6 \\
\hline $\mathrm{ME}\left(\mathrm{kcal} \cdot \mathrm{kg}^{-1}\right)$ & 3300 & 3300 & 3300 \\
\hline
\end{tabular}

HPa: high-protein diet with antibiotics; HP: high-protein diet without antibiotics; LPpb: low-protein diet without antibiotics and with probiotics; *Aminogut, L-glutamine and L-glutamic acid (1:1), (Ajinomoto, Japan); ${ }^{* *}$ Linco Spectin premix, $2.2 \mathrm{~g}$ lincomycin, $2.2 \mathrm{~g}$ spectinomycin (Zoetis, USA); ${ }^{* * *}$ Gustor sodium butyrate, (Norel, Spain); ${ }^{* * * *}$ Bioplus 2B: B. subtilis and B. licheniformis (1:1); (Crh Hansen, Denmark); ${ }^{* * * * *}$ Vitamin and mineral premix: (vitamins per kg of diet: vitamin A 10,200 IU; vitamin D 1980 IU; vitamin E 60

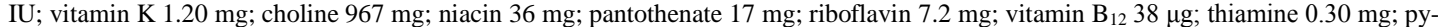
ridoxine $0.31 \mathrm{mg}$; biotin $0.08 \mathrm{mg}$; folate $0.75 \mathrm{mg}$ mineral/kg diet; copper $14.4 \mathrm{mg}$; iodine $800 \mathrm{mg}$; iron $105 \mathrm{mg}$; manganese $36 \mathrm{mg}$; selenium $0.3 \mathrm{mg}$; zinc $144 \mathrm{mg}$ ).

were divided by seven (days of a week). Incidence of diarrhea was measured daily in each pen by direct observation by two different evaluators. The severity of diarrhea was measured through visual evaluation of the fecal consistency, using a score from 0 to 3, where 0 indicated normal feces, 1 indicated mild diarrhea, 2 indicated moderate diarrhea, and 3 indicated severe diarrhea. The daily score of each pen was averaged every week to calculate the severity of diarrhea [3]. 


\subsection{Sampling and Analysis}

At day 21 after weaning, four animals from each group (one per experimental unit [pen]) were stunned using $\mathrm{CO}_{2}$ and euthanized by exsanguination by severing the jugular vein. A midline incision was made in the abdomen to expose the digestive tract. The small and large intestines were removed from the abdominal cavity to collect the terminal ileum and proximal colon digesta, which were immediately frozen in liquid nitrogen and stored at $-80^{\circ} \mathrm{C}$ until analysis. Concentrations of acetic, propionic, butyric, and valeric acids (SCFAs); isobutyric, isovaleric, and isocaproic acids (BCFAs) [15] and lactic acid (LA) [16] were measured by gas chromatography; and ammonia (AM) by distillation [17]. Diets were analyzed by Association of Official Analytical Chemists methods [17]: moisture (934.01), ashes (900.02), crude protein (984.13), crude fat (954.16). Neutral Detergent Fiber (NDF) were measured by Van Soest method [18].

\subsection{Statistical Analysis}

Fermentation profiles were analyzed using a completely randomized design, considering the piglet as the experimental unit. ADG, ADFI, and G:F were analyzed using a completely randomized design, considering the pen as the experimental unit. In both cases, $\alpha$-value of 0.05 was used to assess significance, and means were compared by Tukey's test using the GLM procedure of SAS [19] [20]. The presence and severity of diarrhea were analyzed as repeated measures on a time design, considering the pen as the experimental unit using the Proc Mix procedure of SAS [20].

\section{Results}

\subsection{Microbial Fermentation End Products}

Fermentation profiles in the ileum and colon were affected by diet (Table 2). Piglets fed HPa had lower concentration of total VFAs (Volatile Fatty Acids) $(P<0.001)$ than piglets fed diets without antibiotics (HP and LPpb). The effects of antibiotic on the VFAs profile in the ileum and colon were different. The absence of antibiotic in the HP diet increased SCFA production in the ileum, but decreased SCFA production in the colon $(P<0.001)$. Animals fed the LPpb diet had higher concentration of SCFAs in the ileum and colon $(P<0.001)$ than animals fed the HP or HPa diet. Acetate was the most abundant SCFAs in piglets fed the LPpb diet, followed by butyrate and propionate. Higher concentrations of BCFAs were observed in the digesta, in both ileum and colon, of animals fed the HP diet than in those fed the HPa and LPpb diets $(P<0.001)$. LA concentrations in the ileum and colon were higher in piglets fed the LPpb diet $(P<0.001)$ than in those fed the HP and HPa diets. AM concentrations were higher in animals fed the HP diet $(P<0.001)$ than in those receiving the HPa and LPpb diets (Table 2).

\subsection{Postweaning Diarrhea}

All animals had mild diarrhea throughout the experimental period (Figure 1). However, animals fed the HP diet had the highest incidence and severity of diarrhea $(P<0.01)$, while the other two groups (HPa and LPpb) exhibited similar incidence and severity. The highest incidence and severity of diarrhea were observed during the second week postweaning $(P<0.01)$. Both, incidence and severity of diarrhea, decreased during the third week postweaning $(P<0.01)$, returning to values similar to those observed during the first week postweaning.

\subsection{Performance}

Piglets fed the HPa and LPpb diets showed similar performance parameters $(P>0.05)$ for all weeks and for the entire experimental period (Figure 2). In contrast, animals fed the HP diet had significantly poorer performance than the other two groups of animals $(P<0.05)$, except for ADFI during the first week postweaning and G:F during the second week postweaning.

\section{Discussion}

\subsection{Fermentation Pattern}

The presence of antibiotics and level of dietary protein in the diet modify the fermentative activity of the intes- 
Table 2. Volatile fatty acids, lactic acid $(\mu \mathrm{mol} / \mathrm{g})$, and ammonia $(\mathrm{mg} / \mathrm{kg})$ production in the ileum and colon.

\begin{tabular}{|c|c|c|c|c|c|}
\hline & \multicolumn{3}{|c|}{ Treatments } & \multirow{2}{*}{$P$} & \multirow{2}{*}{ SEM } \\
\hline & $\mathrm{HPa}$ & $H P$ & $L P p b$ & & \\
\hline \multicolumn{6}{|l|}{ Ileum } \\
\hline Acetate & $11^{\mathrm{c}}$ & $15^{\mathrm{b}}$ & $82^{\mathrm{a}}$ & $* * *$ & 0.07 \\
\hline Butyrate & $6.3^{c}$ & $7.3^{\mathrm{b}}$ & $36^{\mathrm{a}}$ & $* * *$ & 0.06 \\
\hline Propionate & $5.2^{\mathrm{b}}$ & $4.3^{c}$ & $27^{\mathrm{a}}$ & $* * *$ & 0.06 \\
\hline Valerate & $7.2^{\mathrm{b}}$ & $19^{\mathrm{a}}$ & $2.1^{\mathrm{c}}$ & ${ }^{* * *}$ & 0.04 \\
\hline Isobutyrate & $2.5^{\mathrm{b}}$ & $32^{\mathrm{a}}$ & $2.2^{\mathrm{c}}$ & $* * *$ & 0.06 \\
\hline Isovalerate & $3.7^{\mathrm{b}}$ & $21^{\mathrm{a}}$ & $1.9^{\mathrm{c}}$ & $* * *$ & 0.06 \\
\hline Isocaproate & $2.2^{\mathrm{b}}$ & $15^{\mathrm{a}}$ & $0.7^{c}$ & $* * *$ & 0.03 \\
\hline VFAs & $38^{c}$ & $116^{\mathrm{b}}$ & $152^{\mathrm{a}}$ & ${ }^{* * *}$ & 0.28 \\
\hline SCFAs & $29^{c}$ & $46^{\mathrm{b}}$ & $147^{\mathrm{a}}$ & $* * *$ & 0.19 \\
\hline BCFAs & $8.5^{\mathrm{b}}$ & $69^{\mathrm{a}}$ & $4.8^{\mathrm{c}}$ & $* * *$ & 0.13 \\
\hline Lactate & $16^{\mathrm{c}}$ & $30^{\mathrm{b}}$ & $41^{\mathrm{a}}$ & ${ }^{* * *}$ & 0.20 \\
\hline Ammonia & $362^{\mathrm{b}}$ & $514^{\mathrm{a}}$ & $190^{\mathrm{c}}$ & ${ }^{* * *}$ & 1.9 \\
\hline \multicolumn{6}{|l|}{ Colon } \\
\hline Acetate & $31^{\mathrm{b}}$ & $19^{c}$ & $121^{\mathrm{a}}$ & $* * *$ & 0.06 \\
\hline Butyrate & $12^{\mathrm{b}}$ & $11^{\mathrm{c}}$ & $46^{\mathrm{a}}$ & $* * *$ & 0.09 \\
\hline Propionate & $11^{\mathrm{b}}$ & $9.4^{\mathrm{c}}$ & $38^{\mathrm{a}}$ & $* * *$ & 0.07 \\
\hline Valerate & $15^{\mathrm{a}}$ & $9.3^{\mathrm{b}}$ & $1.8^{\mathrm{c}}$ & ${ }^{* * *}$ & 0.01 \\
\hline Isobutyrate & $7.5^{\mathrm{b}}$ & $58^{\mathrm{a}}$ & $2.9^{c}$ & $* * *$ & 0.02 \\
\hline Isovalerate & $9.3^{\mathrm{b}}$ & $36^{\mathrm{a}}$ & $2.5^{\mathrm{c}}$ & $* * *$ & 0.04 \\
\hline Isocaproate & $10^{\mathrm{b}}$ & $17^{\mathrm{a}}$ & $1.3^{\mathrm{c}}$ & ${ }^{* * *}$ & 0.01 \\
\hline VFAs & $97^{\mathrm{c}}$ & $162^{\mathrm{b}}$ & $214^{\mathrm{a}}$ & *** & 0.16 \\
\hline SCFAs & $70^{\mathrm{b}}$ & $49^{c}$ & $207^{\mathrm{a}}$ & $* * *$ & 0.12 \\
\hline BCFAs & $27^{\mathrm{b}}$ & $112^{\mathrm{a}}$ & $6.5^{\mathrm{c}}$ & $* * *$ & 0.05 \\
\hline Lactate & $1.2^{\mathrm{c}}$ & $1.9^{\mathrm{b}}$ & $2.3^{\mathrm{a}}$ & $* * *$ & 0.008 \\
\hline Ammonia & $400^{\mathrm{b}}$ & 1077 & $275^{\mathrm{c}}$ & $* * *$ & 4.5 \\
\hline
\end{tabular}

HPa: high-protein diet with antibiotics; HP: high-protein diet without antibiotics; LPpb: low-protein diet without antibiotics and with probiotics; VFAs: volatile fatty acids; SCFAs: short-chain fatty acids; BCFAs: branched-chain fatty acids; ${ }^{* * *} P<0.001$; SEM: standard error of the mean; ${ }^{a b c}$ different letters in the same row show statistical differences.

tinal flora, as demonstrated by the results of the HP and LPpb groups in the present study. Animals in these groups that did not consume antibiotics showed the highest concentrations of the most microbial fermentation products (VFAs). In both, the ileum and colon of these animals, the quantity of VFAs was influenced by the concentration of SCFAs. This was supported by the observation that piglets fed the LPpb diet had higher concentration of SCFAs than animals of the other two groups (HPa and HP) $(P<0.01)$, while piglets fed the HP diet had higher concentration of BCFAs than the other two groups (HPa and LPpb) $(P<0.01)$. Animals fed the LPpb diet exhibited similar profiles of SCFAs in the colon and in the ileum. However, animals fed the HP diet exhibited lower concentrations of SCFAs than those fed the HPa diet (with antibiotics). 

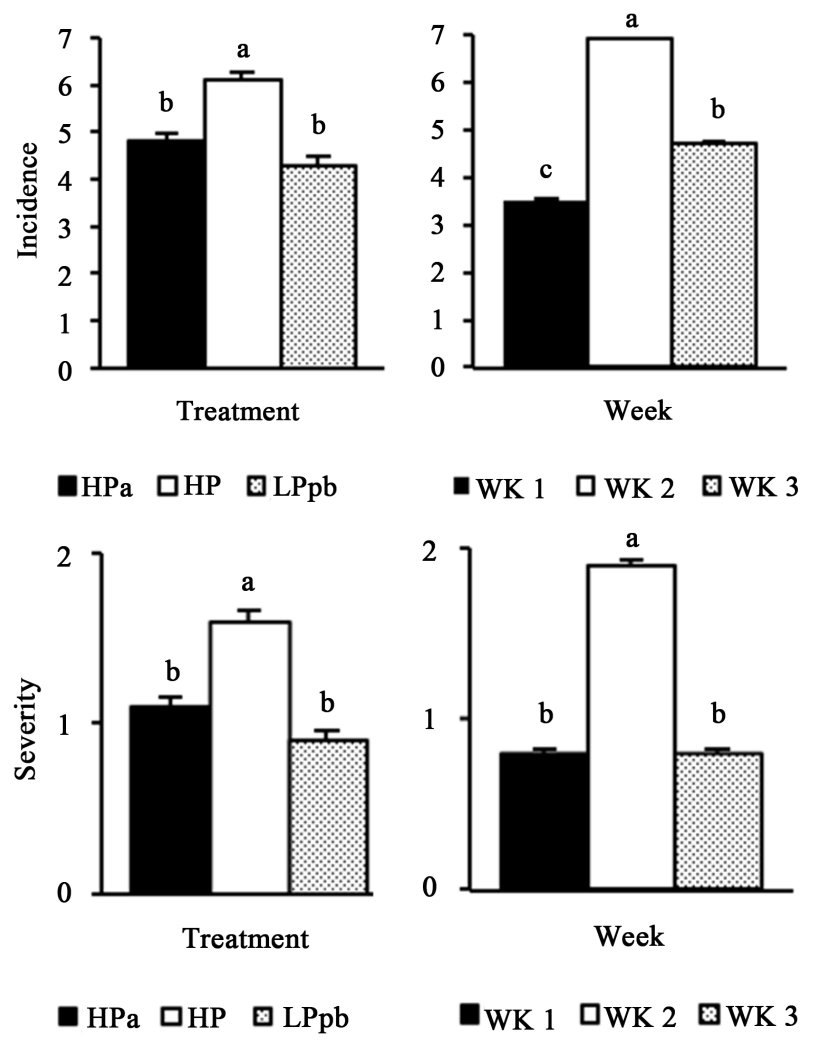

Figure 1. Effect of treatments and postweaning weeks on the incidence and severity of diarrhea. HPa: high-protein diet with antibiotics; HP: high-protein diet without antibiotics; LPpb: low-protein diet without antibiotics and with probiotics; WK1: first week postweaning; WK2: second week postweaning; WK3: third week postweaning; ${ }^{a b c}$ bars with different letters show statistical differences $(P<0.01)$.

These data indicate that antibiotics reduced overall fermentation in the ileum, but both antibiotics and protein levels affected intestinal fermentation in the colon. Indeed, the absence of antibiotics and presence of a large quantity of undigested protein in the hindgut probably favored the growth of microorganisms capable of fermenting protein (BCFAs and AM producers), which could limit the growth of other types of microorganisms (generally SCFAs producers). These results were consistent with those of several other studies [1]-[3] [9] in which the use of antibiotics showed to affect intestinal fermentation.

Microbial fermentation of protein increases AM production and fermentation of branched amino acids, generating BCFAs [2]. Thus, the level of dietary protein is a key factor that modifies the intestinal microenvironment. This idea was supported by the high concentrations of BCFAs and AM in the gut of animals fed the HP diet in the present study. This may be because piglets do not digest dietary protein well, and undigested protein remaining in the intestinal lumen can serve as a substrate for bacterial fermentation. BCFAs and AM are harmful metabolites to intestinal mucosa because they are able to alter the acid-base balance, an essential factor for water absorption in the hindgut, and this is probably one of the triggers postweaning diarrhea [1] [21].

Conversely, when the protein level was reduced and probiotics were added (LPpb diet), SCFAs and LA production were increased. This probably resulted from differences in the quantity of major ingredients of the diet required to reduce the protein level; in the LPpb diet, protein sources were reduced, while corn was increased (Table 1), providing a greater amount of starch, which is an important substrate to amylolytic bacteria, resulting in an increased production of acetic and propionic acids. In turn, acetic acid can be transformed to butyric acid, which provides between $70 \%$ and $90 \%$ of the energy required by colonocytes metabolism [22], thus sparing about 30\% of the energy requirement of piglets during the stressful period weaning represents [1] [22] [23]. Moreover, comparing results in the present study with other conducted by our research group, in which a low- 

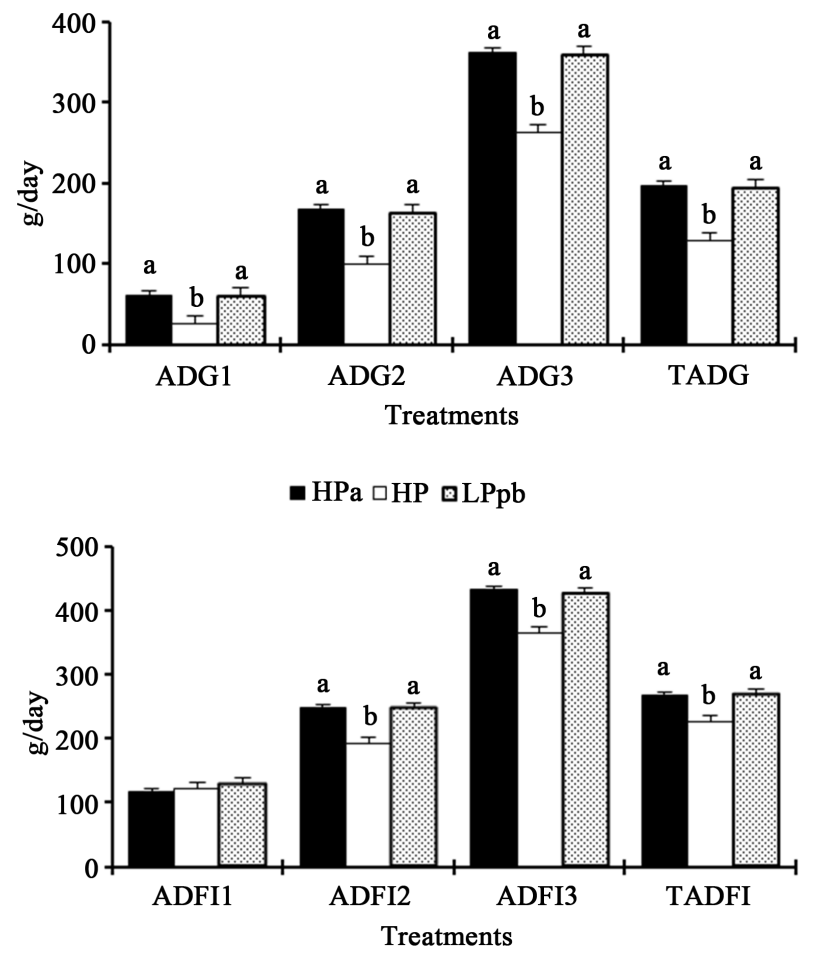

-HPa HP

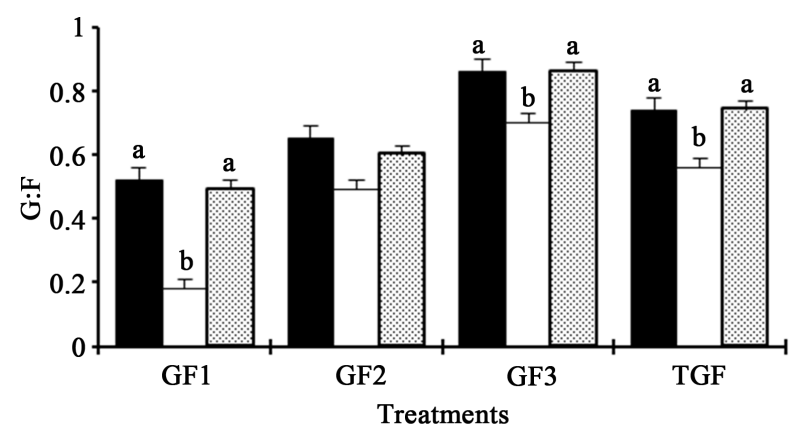

-HPa $\square \mathrm{HP}$ ФLPpb

Figure 2. Effects of dietary protein levels and probiotics on the performance of newly weaned piglets. HPa: high-protein diet with antibiotics; HP: high-protein diet without antibiotics; LPpb: lowprotein diet without antibiotics and with probiotics; ab: bars with different letters show statistical differences; ADG1: average daily gain in week 1; ADG2: average daily gain in week 2; ADG3: average daily gain in week 3 ; TADG: average daily gain during the total experimental period; ADFI1: average daily feed intake in week 1; ADFI2: average daily feed intake in week 2; ADFI3: average daily feed intake in week 3; TAFI: average daily feed intake during the total experimental period; G:F1: gain:feed ratio in week 1; G:F2: gain:feed ratio in week 2; G:F3: gain:feed ratio in week 3; TG:F: total gain:feed ratio.

protein diet without probiotics was used (unpublished data), we can conclude that probiotics supplementation of a low protein diet resulted in a higher proportion of SCFAs, mainly acetic acid, which could be beneficial to the intestinal environment and probably reduce postweaning diarrhea in piglets. 
Furthermore, high concentration of SCFAs reduces gut $\mathrm{pH}$, inhibiting the development of potentially pathogenic bacteria [24]. The higher concentration of LA in the ileum with respect to that in the colon, may be the result of rapid lactose fermentation in the small intestine, causing a reduction in lactose transit to the large bowel. LA also serves as a bacterial control and promotes growth of beneficial bacteria, mainly SCFAs producers [1] [2].

\subsection{Postweaning Diarrhea}

The high incidence and severity of diarrhea in piglets fed the HP diet suggest that high level of dietary protein and the absence of antibiotics triggered postweaning diarrea. This was also observed by others (5 - 9) and may be explained as the fermentation of undigested protein by opportunistic bacteria, which results in an increased production of BCFAs and AM, promoting the incidence and severity of diarrhea [25] [26].

Addition of antibiotics to high-protein diets controls bacterial growth, reduces overall fermentation, and suppresses BCFA and AM production [21] [22]. Reduction of protein levels and addition of probiotics in the diet results in a beneficial fermentation pattern, increasing SCFAs and LA, and reducing BCFA and AM concentrations. These changes may reduce $\mathrm{pH}$ values and in turn decreasing growth of opportunistic bacteria [1] [21]. SCFAs, mainly butyrate, increase glucagon-like peptide 2 (GLP2) secretion by L cells in the ileum. GLP2 stimulates cellular proliferation and maturation, probably allowing a quick recovery of intestinal epithelium, reducing the incidence and severity of postweaning diarrhea [27].

The transient under consumption normally reported during the first three days after weaning, probably reduces the presence of undigested protein in the intestinal lumen, thereby suppressing bacterial fermentation [28]. Consequently, fermentation should not be a determining factor in the incidence of diarrhea during the first week after weaning [28]. However, once piglets increase feed intake (3 - 5 days after weaning) the presence of fermentable substrates (mainly protein) in the intestinal lumen may promote the growth of pathogenic bacteria, resulting in greater production of potentially toxic metabolites, which can damage the intestinal mucosa producing diarrhea [1]. The severity of diarrhea observed during the second week after weaning confirmed this mechanism. Once the animal's digestive capacity increases, the severity of diarrhea decreases [29]; this was observed during the third week after weaning.

The increase in SCFAs observed in piglets fed with the combination of a low-protein diet and probiotics (LPpb diet), compared to those produced by piglets fed a high protein diet, may be the result of intestinal environmental changes favoring the establishment of beneficial microbes and limiting the growth of pathogenic bacteria [22]. These changes may reduce the incidence and severity of postweaning diarrhea and improve piglet's growth. On the other hand, probiotics facilitate the characteristics of the intestinal environment by maintaining an acidic $\mathrm{pH}$, which inhibits the growth of potentially pathogenic bacteria that generally require an alkaline $\mathrm{pH}$ to grow [30] [31]. Beneficial bacteria rapidly proliferate to become more abundant through competitive exclusion, occupying binding sites on the intestinal mucosa that could otherwise be occupied by pathogenic bacteria [32]. Establishment of beneficial bacteria controls pathogenic bacteria proliferation through bacteriocin production, which ruptures the bacterial cell wall through a mechanism similar to that of several antibiotics [30]-[33]. On the other hand, probiotics have demonstrated to modulate the immune system, regulating the expression of pro-inflammatory cytokines, which contribute to the control of postweaning diarrhea [32].

\subsection{Performance}

Low-protein diet contents did not affect performance (ADG, ADFI, and G:F) of piglets (Figure 2). This result was consistent with those of Le Bellego and Noblet [34], who found that diets with low crude protein, supplemented with essential amino acids, were effective to maximize nutrient intake by piglets. Furthermore, a decrease in dietary protein (from 20.4\% to 16.9\%) did not affect the ADFI or ADG of piglets. In the present study, protein levels were slightly lower (16\%), and no differences were observed. Bikker et al. [28] observed that animals fed low-protein diets (15\%) had higher ADFI and ADG than animals fed high protein diets. In a study by Reynolds and O’Doherty [35] feeding a low protein diet to piglets between 0 and 28 days postweaning, resulted in reduced growth rates, probably due to amino acids deficiency, mainly lysine. However, when appropriate amino acids were provided together with a low-protein diet, animal growth was not altered. In the present study, the low protein diet was supplemented with essential amino acids, including lysine, methionine, tryptophan, threonine, and valine; we believe this is the reason why no changes in animal performance was observed. These 
results are consistent with those of Reynoso et al. [36], who found that protein content in the diet could be reduced as long as synthetic amino acids are included to meet the nutritional requirements of piglets. Similarly, Hansen et al. [37] observed the same ADG in piglets fed low (17\%) and high-protein (21\%) diets supplemented with amino acids.

\section{Conclusion}

In the present study, the use of antibiotics reduced microbial fermentation by altering the proliferation of intestinal bacteria. When piglets were fed a high protein diet VFAs concentration was increased, mainly BCFAs. Conversely, the use of a low-protein diet with probiotics promoted SCFAs production. Both high-protein diets with antibiotics and low-protein diets with probiotics promoted healthy intestinal environment, reducing the incidence and severity of diarrhea. Therefore, it can be concluded that feeding a low protein diet combined with probiotics to newly-weaned piglets may have similar effects on incidence and severity of diarrhea and performance, to those fed a high-protein diet with antibiotics. A combination of a low-protein diet and probiotics may be an effective alternative to the use of antibiotics in starter diets.

\section{Acknowledgements}

This study was partially supported by CONACyT grant CB-2012-01000000000179898 and by the Programa Integral de Fortalecimiento Institucional, of the Mexican Ministry of Public Education (SEP).

\section{References}

[1] Williams, B.A., Bosch, M.W., Awati, A., Konstantinov, S.R., Smidt, H., Akkermans, A.D.L., Verstegen, M.W.A. and Tamminga, S. (2005) In Vitro Assessment of Gastrointestinal Tract (GIT) Fermentation in Pigs: Fermentable Substrates and Microbial Activity. Animal Research, 54, 191-201. http://dx.doi.org/10.1051/animres:2005011

[2] Hermes, R.G., Molist, F., Ywazaki, M., Nofrarías, M., Gomez de Segura, A., Gasa, J. and Pérez, J.F. (2009) Effect of Dietary Level of Protein and Fiber on the Productive Performance and Health Status of Piglets. Journal of Animal Science, 87, 3569-3577. http://dx.doi.org/10.2527/jas.2008-1241

[3] Opapeju, F.O., Krause, D.O., Payne, R.L., Rademacher, M. and Nyachoti, C.M. (2009) Effect of Dietary Protein Level on Growth Performance, Indicators of Enteric Health, and Gastrointestinal Microbial Ecology of Weaned Pigs Induced with Postweaning colibacilosis. Journal of Animal Science, 87, 2635-2643. http://dx.doi.org/10.2527/jas.2008-1310

[4] Nyachoti, C.M., Omogbenigun, F.O., Rademacher, M. and Blank, G. (2006) Performance Responses and Indicators of Gastrointestinal Health in Early Weaned Piglets Fed Low-Protein Amino Acid Supplemented Diets. Journal of Animal Science, 84, 125-134.

[5] Htoo, J.K., Araiza, B.A., Sauer, W.C., Rademacher, M., Zhang, Y., Cervantes, M. and Zijlstra, R.T. (2007) Effect of Dietary Protein Content on Ileal Amino Acid Digestibility, Growth Performance, and Formation of Microbial Metabolites in Ileal an Cecaldigesta of Early-Weaned Pigs. Journal of Animal Science, 85, 3303-3312. http://dx.doi.org/10.2527/jas.2007-0105

[6] Wellock, I.J., Fortomaris, P.D., Houdijk, J.G.M. and Kyriazakis, I. (2006) The Effect of Dietary Protein Supply on the Performance and Risk of Post-Weaning Enteric Disorders in Newly Weaned Pigs. Animal Science, 82, 327-335. http://dx.doi.org/10.1079/ASC200643

[7] Yue, L.Y. and Qiao, S.Y. (2008) Effects of Low-Protein Diets Supplemented with Crystalline Amino Acids on Performance and Intestinal Development in Pliglts over the First 2 Weeks after Weaning. Livestock Science, 115, 144-152. http://dx.doi.org/10.1016/j.livsci.2007.06.018

[8] Heo, J.M., Kim, J.C., Hansen, C.F., Mullan, C.F., Hampson, B.P. and Pluske J.R. (2008) Effects of Feeding Low Protein Diets to Piglets on Plasma Urea Nitrogen, Faecal Ammonia Nitrogen, the Incidence of Diarrhea and Performance after Weaning. Archives of Animal Nutrition, 62, 343-358. http://dx.doi.org/10.1080/17450390802327811

[9] Wellock, I.J., Houdijk, J.G.M. and Kyriazakis, I. (2007) Effect of Dietary Non-Starch Polysaccharide Solubility and Inclusion Level on Gut Health and the Risk of Postweaning Enteric Disorders in Newly Weaned Piglets. Livestock Science, 108, 186-189. http://dx.doi.org/10.1016/j.liv.sci.2007.01.050

[10] Bhandari, S.K., Opapeju, F.O., Krause, D.O. and Nyachoti, C.M. (2010) Dietary Protein Level and Probiotic Supplementation Effects on Piglet Response to Escherichia coli K88 Challenge: Performance and Gut Microbial Population. Livestock Science, 133, 185-188. http://dx.doi.org/10.1016/j.livsci.2010.06060

[11] Skjolaas, K.A., Burkey, T.E., Dritz, S.S. and Minton, J.E. (2007) Effects of Salmonella enteric Serovar Typhimurium, or Serovar Choleraesuis, Lactobacillus reuteri and Bacillus licheniformis on Chemokine and Cytokine Expression in 
the Swine Jejunal Epithelial Cell Line, IPEC-J2. Veterinary Immunology and Immunopathology, 115, 299-308. http://dx.doi.org/10.1016/j.vetimm.2006.10.012

[12] Norma Oficial Mexicana, NOM-062-ZOO-1999 (2001) Especificaciones técnicas para la producción, cuidado y uso de los animales de laboratorio. Diario Oficial de la Federación, México, D.F.

[13] CIOMS (1985) International Guiding Principles for Biomedical Research Involving Animals. The Development of Science-Based Guidelines for Laboratory Animal Care. NCBI Bookshelf. http://cioms.ch/publications/guidelines/1985_texts_of_guidelines.htm

[14] National Research Council (NRC) (2012) Nutrients Requirements of Swine. 11th Edition, National Academy Press, Washington DC.

[15] Roberts, S.A., Xin, H., Kerr, B.J., Russell, J.R. and Bregendahl, K. (2007) Effects of Dietary Fiber and Reduced Crude Protein on Ammonia Emission from Laying-Hen Manure. Poultry Science, 86, 1625-1632. http://dx.doi.org/10.1093/ps/86.8.1625

[16] David, F., Sandra, P. and Wylie, P.L. (2003) Improving the Analysis of Fatty Acid Methyl Esters Using Retention Times Locked Methods and Retention Time Data Bases. Agilent Technologies, Santa Clara.

[17] Association of Official Analytical Chemists (AOAC) (2002) Official Methods of Analysis. 17th Edition, Association of Official Analytical Chemists, Arlington.

[18] Van Soest, P.J., Roberts, J. and Lewis, B.A. (1991) Methods for Dietary Fiber Neutral Detergent Fiber and Nonstarch Polysaccharides in Relation to Animal Nutrition. Journal of Dairy Science, 74, 3583-3594. http://dx.doi.org/10.3168/jds.S0022-0302(91)78551-2

[19] Steel, R.G.D. and Torrie, J.H. (1991) Principles and Procedures of Statistics: A Biometrical Approach. 3rd Edition, McGraw-Hill, New York.

[20] SAS Institute (2008) SAS/ETS ${ }^{\circledR} 9.2$ User’s Guide. SAS Institute, Inc., Cary.

[21] Windey, K., De Preter, V. and Verbeke, K. (2012) Relevance of Protein Fermentation to Gut Health. Molecular Nutrition \& Food Research, 56, 184-196. http://dx.doi.org/10.1002/mnfr.201100542

[22] Williams, B.A., Verstegen, M.W.A. and Tamminga, S. (2001) Fermentation in the Large Intestine of Single-Stomached Animals and Its Relationship to Animal Health. Nutrition Research Reviews, 14, 207-227. http://dx.doi.org/10.1079/NRR200127

[23] Donohoe, D.R., Garge, N., Zhang, X., Sun, W., O’Connell, T.M., Bunger, M.K. and Bultman, S.J. (2011) The Microbiome and Butyrate Regulate Energy Metabolism and Autophagy in the Mammalian Colon. Cell Metabolism, 13, 517526. http://dx.doi.org/10.1016/j.cmet.2011.02.018

[24] Taciak, M., Pastuszewska, B., Tuśnio, A. and Święch, E. (2010) Effects of Two Protein and Fibre Sources on SCFA Concentration in Pig Large Intestine. Livestock Science, 133, 138-140. http://dx.doi.org/10.1016/j.livsci.2010.06.046

[25] Blachier, F., Mariotti, F., Huneau, J.F. and Tome, D. (2007) Effects of Amino Acid-Derived Luminal Metabolites on the Colonic Epithelium and Physiopathological Consequences. Amino Acids, 33, 547-562. http://dx.doi.org/10.1007/s00726-006-0477-9

[26] Caliendo, G., Cirino, G., Santagada, V. and Wallace, J.L. (2010) Synthesis and Biological Effects of Hydrogen Sulfide (H2S): Development of H2S-Releasing Drugs as Pharmaceuticals. Journal of Medicinal Chemistry, 53, 6275-6286. http://dx.doi.org/10.1021/jm901638j

[27] Burrin, D.G., Petersen, Y., Stoll, B. and Sanguild, P. (2001) Glucagon-Like Peptide 2: A Nutrient-Responsive Gut Growth Factor. Journal of Nutrition, 131, 709-712.

[28] Bikker, P., Dirkzwager, A., Fledderus, J., Trevisi, P., le Huërou-Luron, I., Lallès, J.P. and Awati, A. (2007) Dietary Protein and Fermentable Carbohydrates Contents Influence Growth Performance and Intestinal Characteristics in Newly Weaned Pigs. Livestock Science, 108, 194-197. http://dx.doi.org/10.1016/j.livsci.2007.01.057

[29] Lallès, J.P., Bosi, P., Smidt, H. and Stokes, C.R. (2007) Weaning-A Challenge to Gut Physiologists. Livestock Science, 108, 82-93. http://dx.doi.org/10.1016/j.livsci.2007.01.091

[30] Le Bon, M., Davies, H.E., Glynn, C., Thompson, C., Madden, M., Wiseman, J., Dodd, C.E.R., Hurdidge, L., Payne, G., Le Treut, Y., Craigon, J., Tötemeyer, S. and Mellits, K.H. (2010) Influence of Probiotics on Gut Health in the Weaned Pig. Livestock Science, 133, 179-181. http://dx.doi.org/10.1016/j.livsci.2010.06.058

[31] Anthony, T., Rajesh, T., Kayalvizhi, N. and Gunasekaran, P. (2009) Influence of Medium Components and Fermentation Conditions on the Production of Bacteriocin(s) by Bacillus licheniformis AnBa9. Bioresource Technology, 100, 872-877. http://dx.doi.org/10.1016/j.biortech.2008.07.027

[32] Walker, W.A. (2008) Mechanisms of Action of Probiotics. Clinical Infectious Diseases, 46, 87-91. http://dx.doi.org/10.1086/523335

[33] Alexopoulos, C., Georgoulakis, E., Tzivara, A., Kyriakis, C.S., Govaris, A. and Kyriakis, S.C. (2004) Field Evaluation 
of the Effect of a Probiotic-Containing Bacillus licheniformis and Bacillus subtilis Spores on the Health Status, Performance and Carcass Quality of Grower and Finisher Pigs. Journal of Veterinary Medicine Series A, 51, 306-312. http://dx.doi.org/10.1111/j.1439-0442.2004.00637.x

[34] Le Bellego, L. and Noblet, J. (2002) Performance and Utilization of Dietary Energy and Amino Acids in Piglets Fed Low Protein Diet. Livestock Production Science, 76, 45-48. http://dx.doi.org/10.1016/S0301-6226(02)00008-8

[35] Reynolds, A.M. and O’Doherty, J.V. (2006) The Effect of Amino Acid Restriction during the Grower Phase on Compensatory Growth, Carcass Composition and Nitrogen Utilization in Grower-Finisher Pigs. Livestock Production Science, 104, 112-120. http://dx.doi.org/10.1016/j.livsci.2006.03.012

[36] Reynoso, E., Cervantes, M., Figueroa, J.L. and Cuca, J.M. (2004) Productive Response of Pigs to Low-Protein Diets Added Synthetic Amino Acids and Yeast Culture. Cuban Journal of Agricultural Science, 38, 269-275.

[37] Hansen, J.A., Knabe, D.A. and Burgoon, K.G. (1993) Amino Acids Supplementation of Low-Protein Sorghum-Soybean Meal Diet for 5 to 20 Kilograms Swine, Journal of Animal Science, 71, 452-458. 
Scientific Research Publishing (SCIRP) is one of the largest Open Access journal publishers. It is currently publishing more than 200 open access, online, peer-reviewed journals covering a wide range of academic disciplines. SCIRP serves the worldwide academic communities and contributes to the progress and application of science with its publication.

Other selected journals from SCIRP are listed as below. Submit your manuscript to us via either submit@scirp.org or Online Submission Portal.
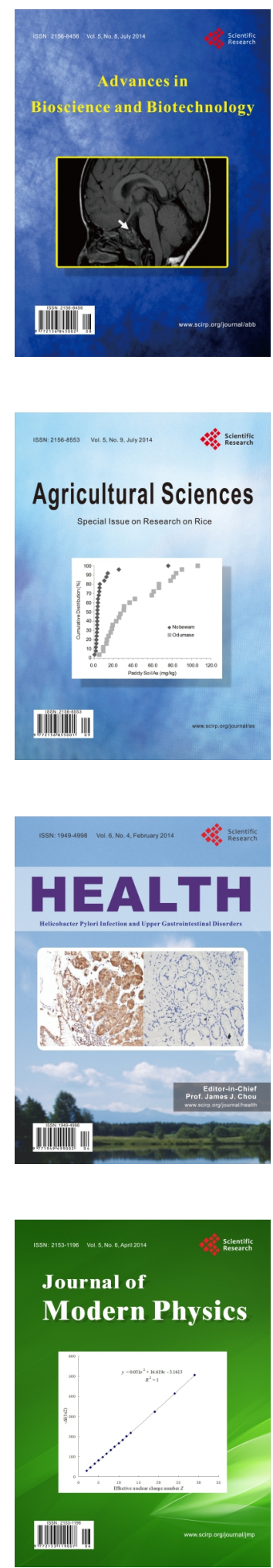
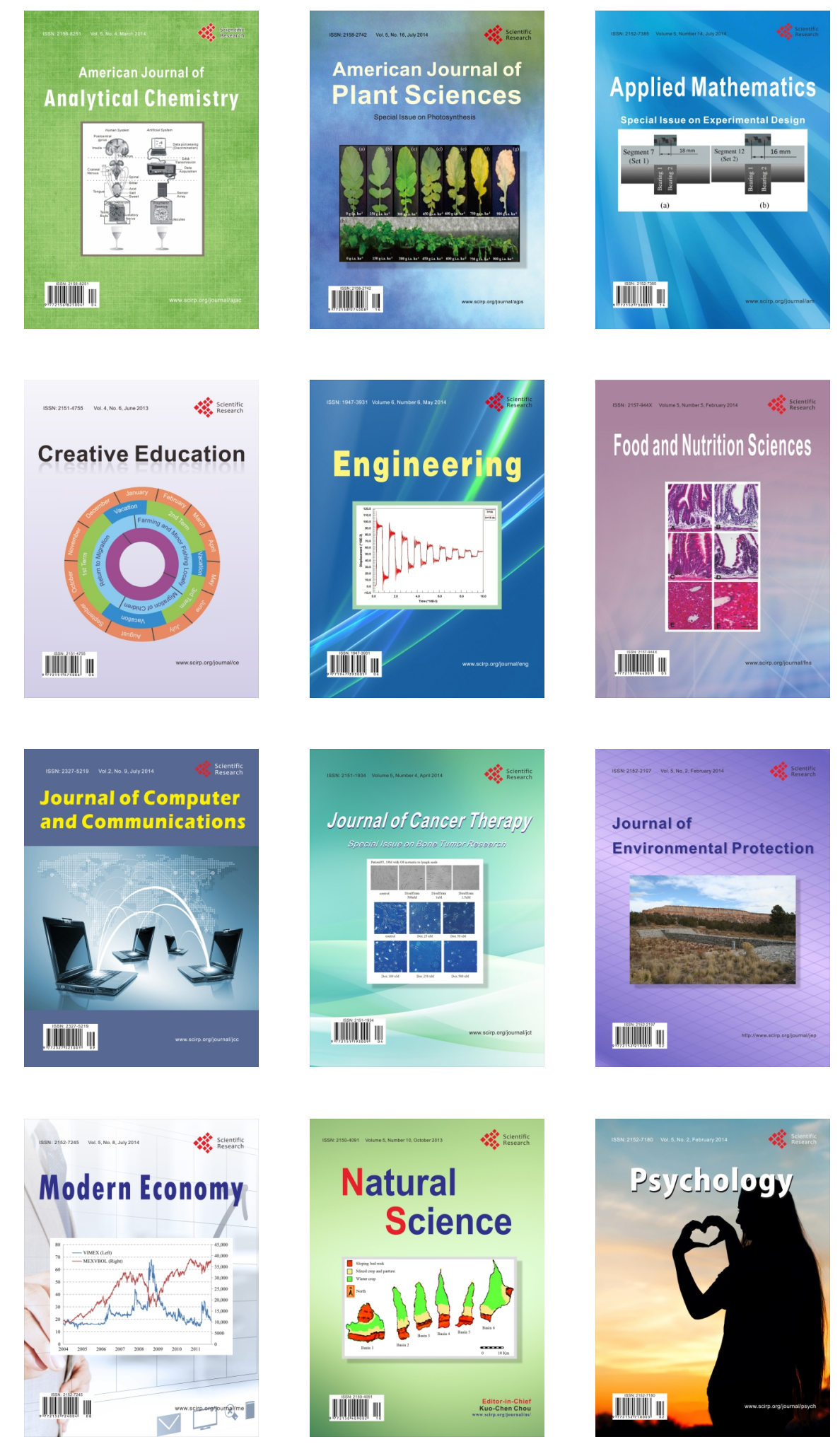